\section{Basilar Skull Fracture: Outcome of Acute Care without Antibiotic Prophylaxis in a Nigerian Neurosurgical Unit}

\author{
Nijerya'da Bir Beyin Cerrahi Yoğun \\ Bakım Ünitesinde Antibiyotik \\ Verilmeksizin Takip Edilen Baziler \\ Kafatası Kırığı Olan Hastalarda Akut \\ Dönem Sonuçları
}

\begin{abstract}
AIM: A prospective observational study of the in-hospital outcome of the management of BSF without antibiotic prophylaxis in a Nigerian neurosurgical unit.

MATERIAL and METHODS: All cases of HI with clinical diagnosis of BSF over an 8-month period were reviewed. Their demographic, clinical, and in-hospital outcome parameters were analysed. We also compared some clinical and outcome characteristics between this study group and a contemporary cohort of patients in our unit with Head Injury but without CSF leak

RESULTS: There were 47 cases. The CSF leak was from the nostrils in $18(38.3 \%)$, the ears in $16(34.04 \%)$, and both ears and nostrils in $12(25.53 \%)$. The cause of injury was road accidents in $91 \%$, and the severity of the Head Injury was mild, moderate and severe respectively in 42.55, 25.53 and $31.91 \%$. Meningitis occurred in 2 patients (4.25\%); in-hospital outcome was good in $68.1 \%$ and poor in $31.9 \%$ and this was significantly $(\mathrm{p}<0.05)$ affected primarily by the severity of the brain injuries. These in-hospital outcome rates and their determinants were similar to those in our unit's contemporary cohort of Head Injury without BSF.

CONCLUSION: Management of traumatic BSF without antibiotic prophylaxis in a developing country setting has not been accompanied with an increased rate of unfavourable outcome.
\end{abstract}

KEYWORDS: Basal skull fracture, Antibiotic prophylaxis, Developing countries, Skull facture

\section{ÖZ}

AMAÇ: Nijerya'da bir beyin cerrahi yoğun bakım ünitesinde antibiyotik profilaksisi verilmeyen kafatası kaide kırıklarının prospektif çalışması.

YÖNTEM ve GEREÇ: 8 aylık dönemde kafa travması geçirip, kafa kaidesi kırığı ile gelen tüm olgular incelendi. Olguların demografik, klinik ve sonuç skorları incelendi. Kohort çalışması yapılarak beyin omurilik kaçağı olan ve olmayan olgular karşılaştırıldı.

BULGULAR: Toplam 47 vaka incelemeye alındı. Vakaların 18 'inde rinore $(\% 38,3)$, 16 'sinda her iki kulaktan otore $(\% 34,04), 12$ 'sinde ise $(\% 25,53)$ hem otore hem de rinore tesbit edildi. Olguların \%91'i yol kazaları nedeni ile kafa travmasına maruz kalmştı. Bu olguların maruz kaldıkları kafa travması hafif, orta, ağır olarak 3 gruba ayrıldı; olguların $\% 42,55$ 'i hafif, $\% 25,53$ 'ü orta ve $\% 31,91$ 'i ise ağır kafa travması olarak değerlendirildi. Olguların 2'sinde menenjit gelişti $(\% 4,25)$. Olguların sonuç skorları \%68,1 hastada iyi olarak, \%31,9'unda ise kötü olarak değerlendirildi $(\mathrm{p}<0,05)$. Kohort çalışması ile kafa kaidesi kırığı olan olgular ile kafa kaidesi kırığı olmayan olguların sonuç skorları arasında benzerlik bulundu. SONUÇ: Gelişmekte olan bir ülkede, kafa kaidesi kırı̆̆ı olan olgularda antibiyotik proflaksisi yapılmaması daha kötü sonuç skoruna neden olmamaktadır.

ANAHTAR SÖZCÜKLER: Bazal kafatası kırığı, Antibiyotik profilaksisi, Gelişmekte olan ülkeler, Kafatası kırı̆̆ı

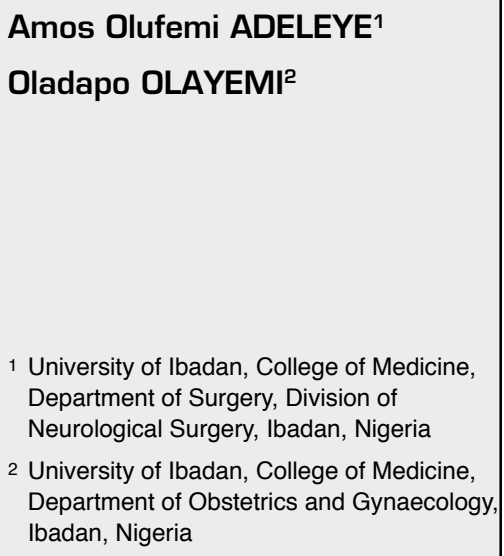

Received : 17.06.2010

Accepted : 15.07.2010

Correspondence address: Amos Olufemi ADELEYE E-mail: femdoy@yahoo.com 


\section{INTRODUCTION}

The controversy surrounding the place of prophylactic antibiotics in the management of basal skull fracture (BSF) leading to traumatic cerebrospinal fluid (CSF) leak is age old $(11,14,21)$. Yet meningitis is a well-known serious complication of BSF (6).For the latter reason, a number of early authors recommended routine use of antibiotic prophylaxis in patients with BSF based on i) the fact that post traumatic CSF leak exposes the intracranial space to contamination, and the development of meningitis, by the nasopharyngeal flora, and ii) their documented high rate of meningitis in patients without prophylaxis $(8,19,21)$. Other authors in the same early era however produced contrasting series showing no benefit of antibiotic prophylaxis $(16,17)$. It was also contended that meningitis does not develop in every patient with BSF and that prophylactic antimicrobial therapy holds the moreharm-than-good potential to actually expose the nasopharyngeal and or the intracranial space in such individuals to more virulent organisms $(17,21)$.

The divergent conclusions of two contemporary meta-analyses on the subject appear to have only further stretched the already well-worn controversy $(11,23)$ even though a much more recent Cochrane meta-analysis would appear to be the beginning of the end of this age long debate (22).

In spite of such great interest on this issue, only few studies from Africa $(2,8)$ and none from the sub-Sahara region are known to us on the place of prophylactic antibiotics in the acute care of traumatic CSF leak from the ear, nose or throat (ENT).

We managed cases of head injury (HI) with associated clinical signs of BSF without the use of antibiotic prophylaxis in a Nigerian neurosurgical unit over an 8-month period. This is a prospective observational study of the in-hospital outcomes of this line of care in a developing country practice setting.

\section{MATERIALS AND METHOD}

A prospective observational analysis of cases of HI with clinical evidence of BSF managed without the use of antibiotic prophylaxis has been carried out. Clinical diagnosis of BSF was made in those cases of $\mathrm{HI}$ with associated CSF leakage from the ear, nose and or throat with or without the other signs like periorbital ecchymosis, subconjunctival haemorrhage and post auricular / mastoid ecchymosis $(6,14)$. They were managed solely with respect to the pathology / severity of their traumatic brain / head injury. Clinical surveillance was maintained for the in-hospital occurrence of meningitis which when suspected was then evaluated and treated with antimicrobials.

These cases of BSF have been drawn out of the total cohort of cases of $\mathrm{HI}$ managed between May and December 2005 in our neurosurgical unit in the Lagos State University Teaching Hospital, Ikeja, Nigeria. Cases with bloody discharge from local trauma to the ENT region were not included in this analysis.

Apart from the age and sex distribution, relevant clinical characteristics reviewed were the cause and severity of the index head injury using the Glasgow coma scale, GCS; the distribution of the CSF efflux in the ear, nose and or throat; associated loss of consciousness (LOC), anisocoria, fever (temperature $>38^{\circ} \mathrm{C}$ ), tachycardia(pulse $>100 /$ minute), hypotension (systolic blood pressure, BP, $<90 \mathrm{mmHg}$ ), presence or absence of associated significant systemic injury and cranial computed tomography (CT) diagnosis of basilar skull fracture. Outcome of management was determined at the time of death or hospital discharge and the measures used were length of hospital stay in days, occurrence of meningitis during the hospital stay, and the Glasgow outcome scale (GOS) on discharge.

Comparison of some clinical and outcome characteristics between these cases of HI with CSF efflux and a contemporary cohort in our unit of HI without CSF efflux was also done. This was with a view to ascertaining any noteworthy difference in these two groups that may impact on their respective clinical management.

Using the Stata 8 statistical software (Statacorp,College Station, TX, USA), descriptive statistics were recorded as frequencies and means with (95\% confidence intervals). Inferential statistics were done with the Pearson's chi-square test (or the Fisher's exact test) for categorical variables, and with Student's $t$ test for continuous variables. The level of statistical significance was set at a $p$ value $<0.05$.

\section{RESULTS}

There were 47 cases of head injury with associated clear or serosanguinous fluid discharge from the ENT passages in which clinical diagnosis of basilar skull fracture was made. These constituted $33 \%$ of 
the 143 cases of head injury managed by us in this study period. Forty-three cases were male and 4 were females, male/ female ratio of 10.75 to 1 . The patients' age range was 1.5 to 68 years; mean and median age being both 30 years. The cause of the head injury was road accident in $91 \%$ of the cases: motor vehicle accident (MVA) in 27 cases $(57.45 \%)$ and motorcycle accident (MCA) in 16 cases (34.04\%). Falls and assaults accounted for the remaining 4 cases.

\section{Clinical Characteristics}

The distribution of the CSF efflux was 18 (38.3\%) from the ears, $16(34.04 \%)$ from the nostrils, $1(2.13 \%)$ from the throat and $12(25.53 \%)$ from both the ears and nostrils.

Using the GCS classification, 20 cases $(42.55 \%)$ had mild, $12(25.53 \%)$ moderate and $15(31.91 \%)$ severe head injuries. There were associated systemic injuries in 15 cases (31.91\%), 11 of which involved the limbs or the pelvis. Forty-one cases $(87.23 \%$ ) had a documented history of loss of consciousness; 5 cases $(10.64 \%)$ had fever, $6(12.77 \%)$ had hypotension, and $12(25.53 \%)$ had anisocoria. Cranial CT was requested in all cases but was obtained in only 16 cases (34.04\%). This revealed evidence of basilar fracture, frontal and or midbasal, in 10 cases, or $62.5 \%$ of the cases that had CT done. Associated intracranial injuries revealed by cranial CT included acute epidural and subdural haematoma in 4 cases and brain contusions / haemorrhage in 14 cases.

\section{In-hospital outcome}

\section{Meningitis}

Two $(4.25 \%)$ in-hospital cases of meningitis were recorded. These were diagnosed clinically with the presence of fever, tachycardia, and clinical meningism (11). Lumbar CSF was seropurulent in one case and serosanguinous in the other. Microbiological study of the CSF samples did not yield any significant culture and both cases were managed successfully with third generation cephalosporins. They were both discharged with GCS of 15 and only moderate deficit on the GOS.

\section{Glasgow Outcome Scale on discharge and determinants of outcome}

Ten cases of in-hospital deaths were recorded representing all-cause mortality rate of $21.28 \%$. Seven cases $(14.89 \%)$ were discharged as normal, 25 $(53.19 \%)$ had moderate deficit, $2(4.26 \%)$ had severe deficit and $3(6.38 \%)$ were in the vegetative state. In other words, 32 cases $(68.1 \%)$ had good outcome on the dichotomised GOS and 15 (31.9\%) had a poor outcome. Fourteen of the 15 cases with a poor outcome were from those with severe head injury (Table I).

Univariate analysis showed the severity of brain injury to have significant effect, $\mathrm{p}<0.001$, on the mortality and poor outcome rate in this cohort of head injury with clinical evidence of basilar skull fracture. Loss of consciousness greater than 48 hours, and presence of anisocoria and hypotension were also significantly associated with worse outcome $(\mathrm{p}<0.05)$ (TableII). There was no significant association between patient's age, presence of fever, or the cause of injury with the outcome status in this study.

No case of meningitis was recorded in the group of head injured patients without CSF leak compared with $2(4.26 \%)$ cases in the cohort with fluid leak. The difference however was not statistically significant.

Table III showed the result of the comparison of some of the clinical and outcome characteristics between these cases of head injury with CSF discharge and a contemporary cohort of head injury withoutCSF efflux managed in our unit. Both groups were of the same age distribution and there were no significant

Table I: Glasgow Outcome Scale Values for Cases of Head Injury with Basilar Fracture Based on the Brain Injury Severity

\begin{tabular}{|l|l|l|l|c|c|c|}
\hline & $\begin{array}{c}\text { Normal } \\
\text { outcome }\end{array}$ & $\begin{array}{c}\text { Moderate } \\
\text { deficit }\end{array}$ & $\begin{array}{c}\text { Severe } \\
\text { deficit }\end{array}$ & $\begin{array}{c}\text { Vegetative } \\
\text { state }\end{array}$ & Death & Total \\
\hline Severity of head injury & & & & & & \\
Mild (GCS 13-15) & $6(30.00)$ & $14(70.00)$ & $0(0.00)$ & $0(0.00)$ & $0(0.00)$ & $20(42.55)$ \\
Moderate (GCS 9-12) & $1(8.33)$ & $10(83.33)$ & $0(0.00)$ & $0(0.00)$ & $1(8.33)$ & $12(25.53)$ \\
Severe (GCS 3-8) & $0(0.00)$ & $1(6.67)$ & $2(13.33)$ & $3(20.00)$ & $9(60.00)$ & $15(31.91)$ \\
\hline Total & $7(14.89)$ & $25(53.19)$ & $2(4.26)$ & $3(6.38)$ & $10(21.28)$ & $47(100.00)$ \\
\hline
\end{tabular}

$p<0.001$, Fisher's exact test; Numbers in parentheses are percentages except otherwise indicated. GCS=Glasgow coma scale; GOS=Glasgow outcome scale 
Table II: Significant Outcome Determinants on the Dichotomised GOS in Cases of Head Injury with Associated CSF Leak

\begin{tabular}{|c|c|c|c|}
\hline $\begin{array}{l}\text { Variable } \\
\qquad=47\end{array}$ & Good outcome & Poor outcome & P value \\
\hline $\begin{array}{r}\text { Loss of consciousness } \\
>48 \mathrm{hrs} \\
<48 \mathrm{hrs}\end{array}$ & $\begin{array}{l}14(48.28) \\
18(100.00)\end{array}$ & $\begin{array}{c}15(51.72) \\
0(0.00)\end{array}$ & 0.002 \\
\hline $\begin{array}{ll}\text { Hypotension } & \\
& \begin{array}{l}\text { Present } \\
\text { Absent }\end{array} \\
\end{array}$ & $\begin{array}{r}1(16.67) \\
31(75.61) \\
\end{array}$ & $\begin{array}{r}5(83.33) \\
10(24.39) \\
\end{array}$ & 0.009 \\
\hline $\begin{array}{ll}\text { Anisocoria } & \\
& \begin{array}{l}\text { Present } \\
\text { Absent }\end{array}\end{array}$ & $\begin{array}{c}3(25.00) \\
29(82.86)\end{array}$ & $\begin{array}{l}9(75.00) \\
6(17.14)\end{array}$ & 0.005 \\
\hline
\end{tabular}

$P$ value on Fisher's exact test. $C S F=$ cerebrospinal fluid, GOS=Glasgow outcome scale

differences $(p>0.05)$ between the two groups with respect to the presence of loss of consciousness, fever, anisocoria and associated systemic injury. Cases with CSF leakage however had significantly longer length of LOC, higher incidence of anisocoria, injury from road accident and of severe head injury than those without ENT efflux. The cranial CT scan of the former was also more likely to reveal evidence of basilar fracture, $\mathrm{p}<0.05$ in each case.

All told, the mortality and poor outcome rate on dichotomised GOS was not significantly different between the two groups. However, a significantly lower proportion (15\%) of the group with CSF efflux was discharged in a normal functional state compared with $(50 \%)$ in those without fluid leakage. Those with CSF discharge also had significantly longer mean length (10.02 days versus 6.90 days) of hospital stay (Table III).

\section{DISCUSSION}

The findings of a prospective observational analysis of cases of head injury with associated CSF leakage from the ear, nose and throat (ENT) in keeping with basilar skull fracture and who were managed without the use of antibiotic prophylaxis in a Nigerian neurosurgical unit have been presented. It appears to be the first such documented analysis in accessible literature from sub-Saharan Africa.

The majority of the patients were young males, outcome of management was significantly determined by the severity of the associated brain injury, presence of anisocoria, hypotension and prolonged unconsciousness (24). Meningitis occurred in-hospital in only 2 patients (4\%) and was successfully managed after diagnosis. The rate of meningitis in basilar skull fracture managed with or without antibiotic prophylaxis varies in the literature possibly due to the heterogeneity of the series concerned. The reported rates include figures such as 9.2 to $17.8 \%$ (23), and 4 to $30 \%(2,14)$.

The all-cause mortality rate of $21 \%$ in this study is also similar to the rate in our earlier series on HI (1) and also similar to the rates in the other low and middle income regions of the world (7).

Compared with our unit's contemporary cohort of HI without BSF however, cases with CSF leak were less likely to be discharged home in the normal functional status on the GOS. This may be due to the fact the latter cases were more severely brain injured and also had a higher incidence of some of the known determinants of poor outcome from $\mathrm{HI}$ like hypotension, anisocoria and prolonged LOC (1, $7,24)$.

\section{Limitations of this study}

Our findings are based on a single hospital unit practice and as such there are limits to which they can be generalised.

We have also not excluded cases of post-traumatic rhinorrhoea/rhinorrhagia and / or otorrhoea/ otorrhagia lasting less than 24 hours from our analysis. This may be one explanation for the high rate $33 \%$ of BSF in our unit head injury cohort compared to the rates of, 3 to $24 \%$ in the literature (23). The prospective nature of our study may also account for our relatively high capture rate of BSF: $75 \%$ of the cases reviewed by Villabalos et al in their meta-analysis were from retrospective studies (23). More specifically to the point of the study 
Table III: Comparison of Some Clinical and Outcome Characteristics Between the Cases of Head Injury with CSF Efflux and a Contemporary Cohort without Efflux

\begin{tabular}{|c|c|c|c|}
\hline Variable & $\begin{array}{c}\text { With CSF efflux } \\
\mathrm{N}=47\end{array}$ & $\begin{array}{l}\text { Without CSF efflux } \\
\qquad \mathrm{N}=96\end{array}$ & $P$ value \\
\hline Mean age (95\% confidence interval) & $30.37(25.79-34.95)$ & $28.57(25.05-32.10)$ & $>0.05$ \\
\hline $\begin{array}{l}\text { Aetiology of HI } \\
\text { Road accident } \\
\text { Others }\end{array}$ & $\begin{array}{c}43(91.49) \\
4(8.51)\end{array}$ & $\begin{array}{l}64(66.67) \\
32(33.33)\end{array}$ & $0.001 b$ \\
\hline $\begin{array}{ll}\text { Severity of HI } & \\
\text { Mild } & \text { (GCS 13-15) } \\
\text { Moderate } & \text { (GCS 9-12) } \\
\text { Severe } & \text { (GCS 3-8) } \\
\end{array}$ & $\begin{array}{l}20(42.55) \\
12(25.53) \\
15(31.91)\end{array}$ & $\begin{array}{l}65(67.71) \\
14(14.58) \\
17(17.71)\end{array}$ & $0.02 \mathrm{a}$ \\
\hline $\begin{array}{c}\text { Loss of consciousness } \\
\text { Present } \\
\text { Absent }\end{array}$ & $\begin{array}{c}43(91.49) \\
4(5.51)\end{array}$ & $\begin{array}{l}83(86.46) \\
13(13.54)\end{array}$ & $0.58 b$ \\
\hline $\begin{array}{l}\text { Duration of loss of consciousness } \\
\quad(95 \% \text { confidence interval) }\end{array}$ & $57.67(36.21-79.13)$ & 21.31(13.42-29.19) & 0.002 \\
\hline $\begin{array}{c}\text { Fever (temperature }>38^{\circ} \mathrm{C} \text { ) } \\
\text { Present } \\
\text { Absent }\end{array}$ & $\begin{array}{r}5(10.64) \\
42(89.36) \\
\end{array}$ & $\begin{array}{c}7(7.29) \\
89(92.71)\end{array}$ & $0.50 \mathrm{a}$ \\
\hline $\begin{array}{c}\text { Tachycardia (pulse }>110 / \text { minute) } \\
\text { Present } \\
\text { Absent }\end{array}$ & $\begin{array}{l}11(23.40) \\
36(76.60)\end{array}$ & $\begin{array}{l}19(19.79) \\
77(80.21)\end{array}$ & $0.14 \mathrm{a}$ \\
\hline $\begin{array}{r}\text { Anisocoria } \\
\text { Present } \\
\text { Absent } \\
\end{array}$ & $\begin{array}{l}12(25.53) \\
35(74.47) \\
\end{array}$ & $\begin{array}{l}12(12.50) \\
84(87.50)\end{array}$ & $0.05 a$ \\
\hline $\begin{array}{c}\text { Associated systemic injury } \\
\text { Present } \\
\text { Absent }\end{array}$ & $\begin{array}{l}15(31.91) \\
32(68.09)\end{array}$ & $\begin{array}{l}23(23.96) \\
73(76.04)\end{array}$ & $0.31 \mathrm{a}$ \\
\hline $\begin{array}{c}\text { Clinical suspicion of basilar fracture } \\
\text { Yes } \\
\text { No }\end{array}$ & $\begin{array}{l}31(65.96) \\
16(34.04)\end{array}$ & $\begin{array}{l}11(11.46) \\
85(88.54)\end{array}$ & $<0.001 \mathrm{a}$ \\
\hline $\begin{array}{l}\text { Basilar fracture on CT scan } \\
(\mathrm{N}=40) \\
\\
\text { Present } \\
\text { Absent }\end{array}$ & $\begin{array}{r}10(62.50) \\
6(37.50)\end{array}$ & $\begin{array}{r}5(20.83) \\
19(79.17)\end{array}$ & $0.05 a$ \\
\hline $\begin{array}{l}\text { Mean length of hospital stay/days } \\
\text { (95\% confidence interval) }\end{array}$ & 10.02(7.29-12.76) & $6.90(5.25-8.54)$ & 0.04 \\
\hline $\begin{array}{l}\text { Outcome at discharge on the GOS } \\
\text { Normal } \\
\text { Moderate deficit } \\
\text { Severe deficit } \\
\text { Vegetative state } \\
\text { Death }\end{array}$ & $\begin{aligned} 7 & (14.89) \\
25 & (53.19) \\
2 & (4.26) \\
3 & (6.38) \\
10 & (21.28)\end{aligned}$ & $\begin{aligned} 48 & (50.00) \\
27 & (28.13) \\
2 & (2.08) \\
1 & (1.01) \\
18 & (18.75)\end{aligned}$ & $<0.001 b$ \\
\hline $\begin{array}{r}\text { Dichotomised GOS } \\
\text { Good outcome } \\
\text { Poor outcome }\end{array}$ & $\begin{array}{l}32(68.08) \\
15(31.92)\end{array}$ & $\begin{array}{l}75(78.13) \\
21(21.87)\end{array}$ & $0.19 a$ \\
\hline
\end{tabular}

$P$ value on student's t test for continuous variable; for categorical variables, $\boldsymbol{a}=$ Pearson's chi-square test, $\boldsymbol{b}=$ Fisher's exact test $\mathbf{C S F}=$ cerebrospinal fluid, $\mathbf{C T}=$ computerised tomography, GCS=Glasgow coma score, GOS=Glasgow outcome scale, $\mathrm{HI}=$ head injury 
however, some authors are of the opinion that the natural history of traumatic CSF leakage lasting less than 24 hours is so innocuous that the justification for antibiotic prophylaxis in them may be tenuous indeed. Nonetheless, it is also known that patients do remain at risk for many years for developing meningitis after the cessation, no matter when, of the post-traumatic CSF leak (9).

In addition, the short-term duration of our outcome study in this series (that is, only in-hospital outcome) is to be kept in view especially knowing that patients remain at risk for intracranial sepsis for many years after the index BSF. However studies with long term follow-up are not only rare $(12,23)$, it is also known that the risk of meningitis in this setting is actually greatest only within the first two weeks of the trauma, dropping sharply after three months $(9,17)$.

\section{Similar studies from this region}

All said, only 2 studies from Africa are known to us on this all-important subject. Both emanated from South Africa in 1992. The first one, a paediatric series, established a low incidence of about $4 \%$ of infective complications with or without prophylactic antibiotics in children with BSF (2). The other study was in adults with open skull fractures, the majority of which were really calvarial. Nevertheless, with $0 \%$ and $13 \%$ rates of meningitis respectively with and without prophylaxis in their cases with BSF, the authors averred that all cases of open and basilar skull fracture should always be covered with antibiotic (8). No other African study on this subject, especially from the sub-Saharan region is known to us and our empirical experience is that opinions are strongly divided in this region on the place of prophylactic antibiotics in the management of cases of HI with suspected fracture of the base of the skull following clinical evidence of CSF leak from the ENT passages.

The place of prophylactic antibiotic in basilar skull fracture

Controversy on this subject however is an ageold, worldwide debate by no means limited to Africa. Hence although meningitis is a well-known serious complication of BSF there are as yet no conclusive studies on the place of prophylactic antibiotics in BSF $(15,22,23)$. While some early authors showed benefits with antibiotic prophylaxis $(8,13,19)$, many others of their contemporaries not only found no such benefits $(2,6,9,16,18)$, some actually showed the use of prophylactic antibiotics to be associated with higher rate of meningitis $(4,5,17)$.

The same debate has persisted till the current era. While there are many case series and few controlled studies showing no benefit for the use of prophylactic antibiotic in BSF $(3,11,20)$, one contemporary study showed the rate of meningitis complicating BSF reduced by about $50 \%$ with prophylaxis (14). More importantly, even two contemporary meta-analyses on the subject in 1997 and 1998 only gave conflicting conclusions, the one for and the other against the use of prophylactic antibiotic in this setting $(11,23)$.

Without doubt, the best way to resolve this long standing, yet critically important, clinical impasse would be the mounting of a properly conducted, and probably multi-centred blinded randomised controlled trial. The big question however is whether even this would materialise soon. One such single unit-based trial proposed since 2006 apparently is yet to be concluded (10).

It appears then that, apart from unit audit experiences as presented in this study, clinical decision making on the need for antibiotic prophylaxis in BSF can, for now, be based on the findings of the recent meta-analyses on this subject $(11,22,23)$.

Conclusions Management of traumatic BSF without antibiotic prophylaxis in a developing country setting has not been attended with increased rate of meningitis or all-cause mortality in this prospective in-hospital study. The place of antibiotic prophylaxis in the acute care of post traumatic skull base fractures remains unresolved, not even from the findings of some recently concluded meta-analyses of the literature on the subject. It is apparent that only properly conducted and well-powered randomized controlled trials could settle this age old clinical controversy.

\section{Abbreviations used in this paper}

$\mathrm{BSF}=$ basilar skull fracture; $\mathrm{CSF}=$ cerebrospinal fluid; $\mathrm{CT}=$ computed tomography; $\mathrm{ENT}=$ ear, nose and throat; GCS=Glasgow coma scale; GOS=Glasgow outcome scale; $\mathrm{HI}=$ head injury; LOC=loss of consciousness; $\mathrm{MCA}=$ motor cycle accident; $\mathrm{MVA}=$ motor vehicle accident 


\section{Competing Interests}

The authors have no competing interests to declare in the conduct or in the writing of the findings of this study.

\section{Authors Contributions}

AOA is the principal investigator, involved in all the stages of the conception, design and conduct of the study. He also wrote the manuscripts through all the stages of its development. He is the corresponding author.

OOO performed the statistical analysis, read the drafts of the manuscript and helped in its critical revisions for intellectual content. He has also given approval for the final version to be published.

\section{ACKNOWLEDGEMENT}

Dr. KG Olowookere, surgical registrar in the department of surgery, Lagos State University Teaching Hospital, Ikeja, Lagos contributed greatly to the gathering of the data for this study

\section{REFERENCES}

1. Adeleye AO, Olowookere KG, Olayemi OO: Clinicoepidemiological profiles and outcomes during first hospital admission of head injury patients in Ikeja, Nigeria. A prospective cohort study. Neuroepidemiology 32: 136-141, 2009

2. Ash GJ, Peter J, Bass DH: Antimicrobial prophylaxis for fractured base of skull in children. Brain Inj 6: 521-527, 1992

3. Bell RB, Dierks EJ, Homer Let al: Management of cerebrospinal fluid leak associated with craniomaxillofacial trauma. J Oral Maxillofac Surg 62: 676-684, 2004

4. Choi D, Spann R: Traumatic cerebrospinal fluid leakage: Risk factors and the use of prophylactic antibiotics. Br J Neurosurg 10: 571-575, 1996

5. Clemenza JW, Kaltman SI, Diamond DL: Craniofacial trauma and cerebrospinal fluid leakage: A retrospective clinical study. J Oral Maxillofac Surg 53: 1004-1007, 1995

6. Dagi TF, Meyer FB, Poletti CA: The incidence and prevention of meningitis after basilar skull fracture. Am J Emerg Med 1: 295-298, 1983

7. De Silva MJ, Roberts I, Perel P, Edwards P, Kenward MG, Fernandes J, Shakur H, Patel P: Patient outcome after traumatic brain injury in high-, middle- and low-income countries: Analysis of data on 8927 patients in 46 countries. Int J Epidemiol 38: 452-458, 2009
8. Demetriades D, Charalambides D, Lakhoo M, Pantanowitz D: Role of prophylactic antibiotics in open and basilar fractures of the skull: A randomized study. Injury 23: 377-380, 1992

9. Dunn LT, Foy PM: Anticonvulsant and antibiotic prophylaxis in head injury. Ann R Coll Surg Engl 76: 147-149, 1994

10. Eftekhar B, Ghodsi M, Hadadi A: Prophylactic antibiotic for prevention of posttraumatic meningitis after traumatic pneumocephalus: Design and rationale of a placebo-controlled randomized multicenter trial [ISRCTN71132784]. Trials 7: 2, 2006

11. Eftekhar B, Ghodsi M, Nejat F, Ketabchi E, Esmaeeli B: Prophylactic administration of ceftriaxone for the prevention of meningitis after traumatic pneumocephalus: Results of a clinical trial. J Neurosurg 101: 757-761, 2004

12. Eljamel MS: Antibiotic prophylaxis in unrepaired CSF fistulae. Br J Neurosurg 7: 501-505, 1993

13. Eljamel MS, Foy PM: Acute traumatic CSF fistulae: The risk of intracranial infection. Br J Neurosurg 4: 381-385, 1990

14. Friedman JA, Ebersold MJ, Quast LM: Post-traumatic cerebrospinal fluid leakage. World J Surg 25: 1062-1066, 2001

15. Haines SJ: Systemic antibiotic prophylaxis in neurological surgery. Neurosurgery 6: 355-361, 1980

16. Hoff JT, Brewin A, U HS Letter: Antibiotics for basilar skull fracture. J Neurosurg 44: 649, 1976

17. Ignelzi RJ, VanderArk GD: Analysis of the treatment of basilar skull fractures with and without antibiotics. J Neurosurg 43: 721-726, 1975

18. Klastersky J, Sadeghi M, Brihaye J: Antimicrobial prophylaxis in patients with rhinorrhea or otorrhea: a double-blind study. Surg Neurol 6: 111-114, 1976

19. Leech PJ, Paterson A: Conservative and operative management for cerebrospinal-fluid leakage after closed head injury. Lancet 1: 1013-1016, 1973

20. McGuirt WF, Jr, Stool SE: Cerebrospinal fluid fistula: the identification and management in pediatric temporal bone fractures. Laryngoscope 105: 359-364, 1995

21. Rathore MH: Do prophylactic antibiotics prevent meningitis after basilar skull fracture? Pediatr Infect Dis J 10: 87-88, 1991

22. Ratilal B, Costa J, Sampaio C: Antibiotic prophylaxis for preventing meningitis in patients with basilar skull fractures. Cochrane Database Syst Rev. 2006, 25:CD004884

23. Villalobos T, Arango C, Kubilis P, Rathore M: Antibiotic prophylaxis after basilar skull fractures: A meta-analysis. Clin Infect Dis 27: 364-369, 1998

24. Yilmazlar S, Arslan E, Kocaeli H, Dogan S, Aksoy K, Korfali E, Doygun M: Cerebrospinal fluid leakage complicating skull base fractures: Analysis of 81 cases. Neurosurg Rev 29: 64-71, 2006 